\title{
Ecosystems under Sail Specimen Transport in the Eighteenth-Century French and British Atlantics
}

\author{
CHRISTOPHER M. PARSONS \\ McNeil Center for Early American Studies \\ and \\ KATHLEEN S. MURPHY \\ California Polytechnic State University
}

\begin{abstract}
The ocean was frequently as hostile an environment for plants and animals as it was for humankind in the eighteenth century. Existing methods of preserving the plants, fish, birds, and land animals that provided the raw materials for European science increasingly proved insufficient for the often long voyages that brought them from colonial and indigenous collectors; specimens arrived dead when they were needed alive, rotten and damaged when they were needed whole, and they frequently suffered as they encountered negligent and uninterested sailors, and rats and other shipboard pests that showed too much interest. This paper examines strategies of specimen transport adopted by French and British naturalists in the Atlantic world during the first half of the eighteenth century, arguing for the importance of maritime spaces that have often been overlooked in histories of the expanding reach of European science. Atlantic networks of specimen transport were simultaneously distinctly national and endlessly entangled. Efforts to discipline maritime social environments diverged along distinctly national lines, influenced by larger patterns of scientific sociability in both Britain and France. At the same time, however, naturalists drew on a cadre of common practices when they packed and preserved specimens for transport. The study of specimen transport demonstrates the geographic expanse of the centripetal and centrifugal tendencies at work more generally in eighteenth-century science; these forces simultaneously strengthened national scientific cultures and supported a cosmopolitan network of naturalists who communicated specimens and the methods for making them throughout Europe and the wider world.
\end{abstract}

Early American Studies (Fall 2012)

Copyright (C) 2012 The McNeil Center for Early American Studies. All rights reserved. 
In 1727 the Virginia planter and naturalist John Custis pessimistically assessed the trans-Atlantic transport of scientific specimens. He thanked Robert Cary for the many plants that he had sent him, but he added, "Of those for the future [give over] the thought of having any such thing sent for I find it is in vain; nothing comes safely but bulbous roots, and these ... ignorance and carelessness can destroy." Custis's experiences of maritime transport of scientific specimens were fairly common in the eighteenthcentury Atlantic world. In 1753 the naturalist and member of the Académie Royale des Sciences Henri-Louis Duhamel du Monceau hinted at the scale of the problem by publishing a specialized text for would-be correspondents. He wrote in his Avis pour le transport par mer des arbres, des plantes vivaces, des semences et de diverses autres curiosités d'bistoire naturelle, "Those who, for their utility, or to satisfy their tastes or those of others, want to transport plants or seeds, or other natural curiosities a great distance, must know that these transports are almost always a pure loss, for lack of necessary precautions." John Ellis, a fellow of the Royal Society, wrote in his 1770 Directions for Bringing Over Seeds and Plants, from the East-Indies and Other Distant Countries that in most cases fewer than one plant in fifty might survive the trip. In the eighteenth century the transportation of botanical and zoological specimens was indeed "an extremely tricky business." 1

By the time that Duhamel du Monceau's and Ellis's instructions were published, travelers had become an essential source of knowledge about the extra-European world; instructions on how to record observations and experiences of use to the European scientific community had been provided to travelers for almost two centuries. Duhamel du Monceau and Ellis, however, drew more specifically on a field of knowledge and a set of practices

1. John Custis to Robert Cary, 1727, in E. G. Swem, ed., "Brothers of the Spade: Correspondence of Peter Collinson, of London, and of John Custis, of Williamsburg, Virginia, 1734-1746," Proceedings of the American Antiquarian Society 58 (April 1948): 38 ("for the future"). Roland-Michel Barrin de La Galissonière and Henri-Louis Duhamel du Monceau, Avis pour le transport par mer des arbres, des plantes vivaces, des semences, des animaux et de diverses autres curiosités d'histoire naturelle (1752), 1-2; John Ellis, Directions for Bringing Over Seeds and Plants, from the East-Indies and Other Distant Countries, in a State of Vegetation (London, 1770), 1; Nigel Rigby, "The Politics and Pragmatics of Seaborne Plant Transportation, 1769-1805," in Margaret Lincoln, ed., Science and Exploration in the Pacific: European Voyages to the Southern Oceans in the Eighteenth Century (Rochester, N.Y.: Boydell Press, 1998), 84 ("tricky business"). 
that had circulated in naturalists' correspondence and between institutions such as royal gardens. It was knowledge acquired through hard experience and frequent loss. In 1740, after reporting that their latest experiments in preservation during transport had been a success, a London-based naturalist complained to his American correspondent, "I wish Wee had been so Lucky to have thought of this Method before, thy pains \& so many fine plants had not been lost."

This article examines a broad range of often familiar sources, including naturalists' correspondence and printed scientific texts, to discuss the nature of specimen transport in the Atlantic world during the first half of the eighteenth century. Comparing the strategies adopted by French and British naturalists reveals histories that are simultaneously distinctive and thoroughly entangled. The maritime social environments through which specimens traveled diverged along distinctly national lines, influenced by larger patterns of scientific sociability in both Britain and France. Whereas the Académie Royale des Sciences enjoyed a level of state support that was the envy of naturalists in England, members of the Royal Society were forced to rely to a far greater extent on commercial networks and personal relationships. In spite of structural differences between French and British Atlantic networks, however, naturalists affiliated with both the Académie and the Royal Society drew on a cadre of common-if heterogeneouspractices when they packed and preserved specimens for maritime transport. Advancements in the production of durable specimens circulated freely in personal correspondence and scientific journals, which encouraged uniformity in the material practices of naturalists throughout North America and Europe. The study of specimen transport demonstrates the geographic expanse of the centripetal and centrifugal tendencies at work more generally in eighteenth-century science; those forces simultaneously strengthened national scientific cultures and supported a cosmopolitan network of natu-

2. The instructions provided to travelers and correspondents have not received a great deal of scholarly attention. Lorelaï Kury, "Les instructions de voyages dans les expéditions scientifiques françaises (1750-1830)," Revue d'Histoire des Sciences 51, no. 1 (1998): 65-92. For a brief transnational analysis of these instructions, see the introduction in Silvia Collini and Antonella Vannoni, Les instructions scientifiques pour les voyageurs (XVIIe-XIXe siècle) (Paris: L'Harmattan, 2005), 15-54. Also see Y.-M. Allain, Voyages et survie des plantes au temps de la voile (Marly-le-Roi, France: Editions Champflour, 2000), chap. 1. Peter Collinson to John Bartram, February 25, 1741, in The Correspondence of John Bartram, ed. Edmund Berkeley and Dorothy Smith Berkeley (Gainesville: University Press of Florida, 1992), 148 ("I wish Wee"). 
ralists who communicated specimens and the methods for making them travel throughout Europe and the wider world. ${ }^{3}$

Recent work on both colonial and Enlightenment science has highlighted the Atlantic context of eighteenth-century natural history. Trans-Atlantic correspondence networks, debates over epistemic authority, plants and animals as discursive objects in texts, and American scientific societies have all received recent and innovative attention from scholars of the early modern Americas. Yet the social and material practices of preservation and transAtlantic transportation are generally absent from this literature; the Atlantic is largely missing from this Atlantic history. Such works occasionally acknowledge the difficulties of transporting delicate seeds, plants, and animals across the Atlantic Ocean, but how these difficulties were surmounted and how such practices shaped the knowledge produced remain unanswered questions. Eighteenth-century naturalists understood the effect that shipboard social and material environments had on the quantity and quality of their specimens, but historians have most often "black-boxed" this crucial stage in the production of new natural knowledge. ${ }^{4}$

3. For a discussion of the limitations of studies that impose national or imperial frameworks on Atlantic history and that encourage conceptions of the Atlantic world as an entangled whole, see Jorge Cañizares Esguerra, Puritan Conquistadors: Iberianizing the Atlantic, 1550-1700 (Stanford: Stanford University Press, 2006), esp. chap. 6; see also the articles in the forum "Entangled Empires in the Atlantic World" in American Historical Review 112, no. 3 (2007), particularly Eliga H. Gould, "Entangled Histories, Entangled Worlds: The English-Speaking Atlantic as a Spanish Periphery," 764-86. For an overview of the different cultures of the Royal Society of London and Académie Royale des Sciences, see James E. McClellan III, Science Reorganized: Scientific Societies in the Eighteenth Century (New York: Columbia University Press, 1985), esp. chap. 1; Robert Fox, "Science and Government," in Roy Porter, ed., The Cambridge History of Science, vol. 4, The Eighteenth Century (Cambridge: Cambridge University Press, 2003), 107-28.

4. For a start, see Ralph Bauer, The Cultural Geography of Colonial American Literatures (Cambridge: Cambridge University Press, 2003); Joyce Chaplin, Subject Matter: Technology, the Body, and Science on the Anglo-American Frontier, 1500-1676 (Cambridge: Harvard University Press, 2001); James Delbourgo, A Most Amazing Scene of Wonders: Electricity and Enlightenment in Early America (Cambridge: Harvard University Press, 2006); James Delbourgo and Nicholas Dew, eds., Science and Empire in the Atlantic World (New York: Routledge, 2008); Sara S. Gronim, Everyday Nature: Knowledge of the Natural World in Colonial New York (New Brunswick: Rutgers University Press, 2007); James E. McClellan III, Colonialism and Science: Saint Domingue in the Old Regime (Baltimore: Johns Hopkins University Press, 1992); Susan Scott Parrish, American Curiosity: Cultures of Natural History in the Colonial British Atlantic World (Chapel Hill: University of North Carolina Press, 2006); François Regourd, "Capitale savante, capitale coloniale: Sciences et savoirs 
As the scale of European scientific networks grew, naturalists faced logistical issues that directly affected the character and content of their work. Plants and animals from the extra-European world became what the science studies scholar Bruno Latour has referred to as "immutable and combinable mobiles," objects that because portable and stable could be compared and combined, allowing for simultaneous study on a global scale. Access to large collections of specimens lent authority to the nascent fields of botany and zoology in Paris and London. Naturalists required not just specimens, however, but specimens prepared and transported in particular ways. This article argues that as eighteenth-century naturalists obsessed over the minute details of maritime transport, they became increasingly conscious of oceangoing ships as what, following Dorinda Outram, might be called a space of natural history. Ships were imagined as complex ecosystems, as intricate assemblages of people, animals, and climatic conditions. Naturalists' social and material practices targeted the biotic and abiotic components of the shipboard environment that frequently determined whether a shipment of specimens would arrive intact. Like those of the more familiar spaces of natural history, such as botanical gardens and museums, the particularities of the shipboard space influenced the knowledge produced within it. ${ }^{5}$

The history of specimen transport therefore forces us to appreciate the importance of maritime spaces that have often been overlooked in histories of the expanding reach of European scientific centers; it traces networks that were simultaneously distinctly national and endlessly entangled, encompassing transimperial circuits of scientific exchange that were evolving under the influence of emerging national scientific cultures. It also includes a diverse cast of captains, crews, and oceangoing passengers in histories of Atlantic and colonial science that have often reduced the rela-

coloniaux à Paris aux XVIIe et XVIIIe siècles," Revue d'Histoire Moderne et Contemporaine 55, no. 2 (2008): 121-51; Londa Schiebinger, Plants and Empire: Colonial Bioprospecting in the Atlantic World (Cambridge: Harvard University Press, 2004). Bruno Latour argues that black-boxing effaces the contingent and disputed nature of knowledge production in accounts that emphasize the inevitability of the process. Bruno Latour, Science in Action (Cambridge: Harvard University Press, 1987), 2, 81-82.

5. Dorinda Outram, "New Spaces in Natural History," in N. Jardine, J. A Secord, and E. C. Spary, eds., Cultures of Natural History (Cambridge: Cambridge University Press, 1996), 249-65. Historians of cartography and astronomy have paid far closer attention to ships as sites of knowledge production. See, for example, Richard Sorrenson, "The Ship as a Scientific Instrument in the Eighteenth Century," Osiris, 2nd ser., 11, Science in the Field (1996): 221-36. 
tionship to an ongoing struggle between metropolitan and colonial naturalists.

\section{MARITIME SOCIAL SPACES AND NATURAL HISTORY SPECIMENS}

In 1774 Gabriel de Clieu wrote a letter to the literary journal L'Année Littéraire in an effort to clarify his own place in the history of the introduction of coffee to the New World. In the letter he drew the attention of the journal's reader and audience not just to Paris's Jardin du Roi, where cuttings of the plant were collected in 1723, but to his own efforts to safeguard them during transport across the ocean. "It is useless," he wrote, "to enter into the details of the infinite cares that I had to give to this delicate plant during the long crossing." Nonetheless he did so, explaining that "as water became rare and was rationed on the ship that was carrying me, I shared the little that was given to me with this dear plant." Yet there were those who were "jealous of the happiness that I found in being useful to my homeland," those who sought to damage the plant or take it for themselves. His letter equated the act of sharing water with a plant and safeguarding it during transport with selfless service to both the king and the French people. ${ }^{6}$

Though the transport of the coffee plant represented a pivotal moment in the history of Caribbean ecosystems and economies, naturalists in both Paris and London regularly sought allies on the ships that carried their specimens across the Atlantic who equaled de Clieu in their passion and commitment. Naturalists were just as concerned with the social environments through which their specimens traveled across the Atlantic Ocean as with the rats, cats, and persistent moisture that plagued trans-Atlantic vessels. In spite of the many dangers aboard these ships, for example, John Custis remained convinced that the most essential preparation for transport was to place the specimens "into carefull hands." As these authors grasped for effective means to stabilize and regulate the often tumultuous shipboard environments, they showed an acute awareness of the limits of their own authority and control over their specimens once out to sea. If naturalists therefore studied maritime social spaces with the same vigor that characterized their discussions of American nature, their attempts to manipulate

6. Gabriel de Clieu, "Lettre de M. de Clieu, ancien Capitaine de Vaisseaux, ancien Gouverneur de la Guadeloupe, \& Grand Croix de l'Ordre Royal \& Militaire de Saint Louis, à l'Auteur de ces Feuilles," Année Littéraire 6 (1774): 218-19; see also Ina Baghdiantz McCabe, Orientalism in Early Modern France: Eurasian Trade Exoticism and the Ancien Regime (New York: Berg, 2008), 206-7. 
them took on distinctly national characters as they made use of tools unique to the scientific cultures of France and Britain. ${ }^{7}$

Anxiety, frustration, and pessimism were near-constant features of discussions of environments most often characterized by their unpredictability and unreliability. In 1741, for example, Custis transformed a complaint about a specific captain's lack of attention into a more general criticism of the social world of ships. "I very believe Capt Harding had strict orders from his Master to take care of the plants sent," he wrote, "but not only he but most if not all the Masters take little notice of such orders when they are out of sight." Lost or damaged collections not only threatened the labor required to produce them, but also risked upsetting the frequently tenuous relationships between American collectors and their London- and Parisbased patrons. In the fall of 1754, for example, the Quebec-based naturalist Jean-François Gaultier worried that his rapport with his Parisian patrons had suffered because of the failings of his Atlantic intermediary; that fall he wrote a letter in which he apologized profusely to René Antoine Ferchault de Réaumur, explaining that the specimens that he had sent him would be useless, for he had found the specimens' labels left behind by the person he had charged to transport them. Networks of scientific sociability in the Atlantic world depended on the regular and reliable shipment of natural history specimens; choosing the right hands to usher and protect specimens during transport between North America and Europe was a near-constant preoccupation of metropolitan and colonial naturalists alike. ${ }^{8}$

In the face of the many dangers confronting seagoing collections, the ideal solution was for naturalists to travel with their specimens. John Ellis made clear that the ideal correspondent would accompany his (an ideal correspondent was almost always a male correspondent) specimens and care for them on the voyage back to England. This, he suggested, would ensure

7. John Custis to Robert Cary, 1726, in Swem, "Brothers of the Spade," 38. For the importance of trust and credibility see Steven Shapin, A Social History of Truth: Civility and Science in Seventeenth-Century England (Chicago: University of Chicago Press, 1994).

8. John Custis to Peter Collinson, [summer 1741?], in Swem, "Brothers of the Spade," 91; Gaultier to Réaumur, August 28, 1753, in Arthur Vallée, ed., "Cinq lettres inédites de Jean François Gaultier à M. Réaumur de l'Académie des Sciences," Mémoire de la Société Royale du Canada, 3rd ser., 24 (1930): 40. This anxiety is emblematic of broader anxieties about the reliability and regularity of the information networks of European empires. See Ann Laura Stoler, Along the Archival Grain: Epistemic Anxieties and Colonial Common Sense (Princeton: Princeton University Press, 2009). 
not only that plants and seeds were properly preserved, but that traveling naturalists would be able to alter and adapt their methods over the course of the voyage. Other metropolitan naturalists, such as Duhamel du Monceau, implicitly made the same suggestion; he advised his readers to make sure that they watered plants from time to time during transport, and that they adapt their care to changing weather. In New France and Louisiana at least some botanically inclined missionaries, such as the Jesuit Joseph-François Lafitau and the Abbé Jean-Baptiste Gosselin, took their specimens to France as they crossed the Atlantic on the business of their missions and orders. Military officers such as Jacques-Pierre Daneau du Muy, who collected in the interior of the continent, also had occasion to present their specimens to the court and Académie in person. Yet often this sort of travel was neither possible nor desirable; whether because of competing commitments in the colonies or because of the costs involved, few naturalists were able to shepherd the specimens that they collected across the Atlantic. ${ }^{9}$

The passengers and crews aboard trans-Atlantic vessels were often therefore subjects of the scientific instructions written in the seventeenth and eighteenth centuries rather than an intended audience. Buried within discussions about the transport of natural history specimens, considerations of the innate intellectual ability and competency of sailors and ship captains littered the correspondence of both English and French naturalists in the eighteenth century. Whenever possible, naturalists sought to lodge their specimens in the care of genteel passengers, ship surgeons, or captains, rather than the sailors who constituted the majority of men on board vessels. Indeed, naturalists were more likely to add sailors to the list of pests or dangers trans-Atlantic vessels harbored. At least occasionally such a view was justified, such as when sailors stole the terrapins John Bartram intended for his English patron. ${ }^{10}$

9. Ellis, Directions, 6-7; de la Galissonière and Duhamel du Monceau, Avis pour le transport par mer, 22; Joseph-François Lafitau addressed the Académie Royale des Sciences to discuss his claim that he discovered ginseng in North America. Details are scant on Gosselin's trip. See Catherine Fortin-Morisset, "Gosselin, JeanBaptiste," in Dictionary of Canadian Biography Online, www.biographi.ca/009004119.01-e.php?\&id_nbr $=1378 \& \& P H P S E S S I D=56 k n i b l d i u l n 4 n j p a m b j k 03 p j 4$ (accessed April 11, 2012); Centre des Archives d'Outre-mer (hereafter CAOM), C11C, vol. 65, f. 140 (Daneau du Muy).

10. Peter Collinson to John Bartram, February 3, 1736, in Correspondence of John Bartram, 17. Collinson noted (ibid.) that the ship's captain "made all the amends he could \& gave me one that he had." Sedentary naturalists were also forced to rely on-and weigh the merits of - the recorded observations of a wide assortment of travelers and would-be correspondents. See Shapin, Social History of Truth, esp. 
Passengers making the trans-Atlantic crossing therefore often found themselves besieged with requests to transport everything from plants and letters to bottles of "a Most Extraordinary Animal of the Caterpillar Kind" and collections of Antiguan shells. Such informal arrangements could not only save naturalists the costs of shipping, but also save the intended recipients the trouble of collecting the shipment from the docks or customhouse. Passengers, naturalists hoped, would also be more likely to remember their charges and carefully look after the plants, seeds, and other specimens in their care. In 1736 the English naturalist Peter Collinson entrusted a shipment of European plants intended for Custis to a group of passengers, predicting that "it might be a pretty amusement for them to peep \& Look after" the case of plants. Apparently they found other amusements, for the passengers neglected to water the plants. Despite the occasional failure, most colonial naturalists preferred sending American biota with passengers, especially friends or acquaintances. In 1734 Robert Millar, a traveling naturalist in the employ of the Trustees of Georgia, sent Hans Sloane "two large Jarrs of the best Tamarinds I can purchase" from Kingston, Jamaica. To ensure their safe arrival, Millar "delivered them to the care of one Mr. Gordon a Gentleman going home from this Island, he has promised me to take particular care of them and deliver them at your house himself without giving you any trouble of sending to the Custom House about them." Similarly, in 1759 Governor George Haldane of Jamaica reported to the Duke of Newcastle, the first Lord of the Treasury, that he had delayed sending a promised collection of plants because it was too fine a collection "to venture them solely under the trust of a sea Captain." Instead, Haldane promised to send the collection under the personal care of a friend who would sail to London the following month. ${ }^{11}$

chap. 6; For a discussion of naturalists as moral managers, see E. C. Spary, Utopia's Garden: French Natural History from Old Regime to Revolution (Chicago: University of Chicago Press, 2000), esp. chap. 2.

11. For examples see John Clayton to John Bartram, February 23, 1761, "Letters of John Clayton, John Bartram, Peter Collinson, William Byrd \& Isham Randolph," William and Mary Quarterly, 2nd ser., 6 (1926): 319-21 (plants); Joshua Steele to Joseph Banks, ca. 1780, Add. MS 33977, f. 124, British Library (caterpillar); William Aillidephe to Hans Sloane, June 25, 1734, Sloane 4053, f. 237, British Library (shells); Peter Collinson to John Custis, November 12, 1736, in Swem, "Brothers of the Spade," 51; Custis to Collinson, May 28, 1737, in The Letterbook of John Custis IV of Williamsburg, 1717-1742, ed. Josephine Little Zuppan (Lanham, Md.: Rowman \& Littlefield, 2005), 177; Robert Millar to Hans Sloane, July 22, 1734, Sloane 4055, f. 147, British Library; George Haldane to the Duke of Newcastle, June 1, 1759, Add. MS 32891, ff.387-88, British Library. The practice of con- 
British naturalists relied on the routes of commerce and their connections among merchants, mariners, and passengers to transport American naturalia. In the British Atlantic natural philosophy was pursued and funded by private gentlemen. Although the Royal Society of London occasionally undertook projects that might be of use to the British Empire, it was a private institution that received no funding from the government. When British naturalists wished to transport specimens across the Atlantic, they therefore relied on commercial connections and personal favors. The rhythms of trans-Atlantic commerce rather than the desires of naturalists determined when and how specimens reached their intended destinations. British ship captains and ship surgeons who spent weeks or even months in colonial ports awaiting their cargo returned to England with detailed, local knowledge of the people and natural productions of the places they visited. They bridged the Atlantic in tangible ways, delivering gossip, letters, books, and presents, as well as specimens. Captain William Halsteed, who regularly plied the South Carolina trade, reported on the welfare, health, and collecting activities of the English apothecary and naturalist James Petiver's correspondents in the colony. In 1700 Halsteed wrote from Charles Town to inform Petiver that "this morning I dranck with Mr. [Edmund] Bohun and Mr. [Robert] Ellis they tell me they have sent you home a very fine Collection. I am preparing to do the same." While in the Carolinian port on business, Halsteed met with two of Petiver's most active collectors, delivering books of plants on the apothecary's behalf, drinking to his health, and preparing specimens for his collection. ${ }^{12}$

signing packages and letters to travelers was a common one in the eighteenth century. See Joseph Adelman, “'A Constitutional Conveyance of Intelligence, Public and Private': The Post Office, the Business of Printing, and the American Revolution," Enterprise E Society 11, no. 4 (2010): 714-21; William Smith, The History of the Post Office in British North America, 1639-1870 (New York: Octagon Books, 1973), 25, 51-54.

12. William Halsteed to James Petiver, May 1, 1700, Sloane 4063, f. 18, British Library. On the limits of state support for British science, see Richard Drayton, "Knowledge and Empire," in J. P. Marshall, ed., The Oxford History of the British Empire, vol. 2, The Eighteenth Century (Oxford: Oxford University Press, 1998), 236-43. For the overlap between science and commerce more generally, see Harold J. Cook, Matters of Exchange: Commerce, Medicine, and Science in the Dutch Golden Age (New Haven: Yale University Press, 2007); Delbourgo and Dew, Science and Empire, 1-28, esp. 11; Nicholas Dew, "Vers la ligne: Circulating Measurements around the French Atlantic," in Delbourgo and Dew, Science and Empire, 53-72; Pamela H. Smith and Paula Findlen, eds., Merchants and Marvels: Commerce, Science and Art in Early Modern Europe (New York: Routledge, 2002); Schiebinger, Plants and Empire, 10; Londa Schiebinger and Claudia Swan, eds., Colonial Botany: Sci- 
Maritime men, particularly ship surgeons and captains such as Halsteed, had the mobility and range of contacts necessary to recruit new members of scientific networks. On Petiver's behalf, Halsteed recruited Hannah Williams and Joseph Lord of South Carolina, and the Jamaicans Henry Passmore, Roger and John Fenwick, and Anthony Bigg and his son all became correspondents of Petiver through the good offices of Captain Patrick Rattray. Petiver supplied these potential recruiters with extra copies of his publications to bestow on any colonials who were interested in natural history and who might become new correspondents. When Rattray learned in 1698 that John Fenwick possessed a fine collection of Jamaican plants, he gave the colonist copies of Petiver's publications. In exchange, the colonial presented Rattray with dried plants and seeds to give Petiver upon the shipmaster's return to London. Petiver reciprocated by sending Fenwick collecting supplies such as brown paper and an array of pressed English plants to encourage the colonial to continue sending specimens. Through such gifts of scientific publications and collecting supplies, naturalists like Petiver hoped to oblige colonial correspondents to reciprocate with specimens of New World nature. These gifts also provided colonials with the tools necessary to follow increasingly standardized European practices for the collection and preservation of specimens. ${ }^{13}$

Without a safe, reliable means of transportation, even the most extensive network of collectors paid no dividends. English naturalists therefore needed to convince ship captains to carry their shipments of specimens. Yet as the Virginian Custis complained to his English correspondent Collinson, "few of the Masters care to carry tubs or casks of dirt on their decks." Tubs of plants and boxes of seeds had to compete for space with cargo that was both more profitable and less troublesome. In 1741 John Norton, a merchant in the Virginia trade and a friend of Custis, promised to deliver a box

ence, Commerce and Politics in the Early Modern World (Philadelphia: University of Pennsylvania Press, 2005); Larry Stewart, "Global Pillage: Science, Commerce, and Empire," in Porter, Cambridge History of Science, 4:825-44.

13. For Rattray's and Halsteed's recruiting see Raymond Phineas Stearns, Science in the British Colonies of America (Urbana: University of Illinois Press, 1970), 297, 365; James Petiver to John Fenwick, May 25, 1698, Sloane 3333, f. 131-33, British Library; Marcel Mauss, The Gift: The Form and Reason for Exchange in Archaic Societies, trans. W. D. Halls (New York: W. W. Norton, 2000), 12; Paula Findlen, "The Economy of Scientific Exchange in Early Modern Italy," in Bruce T. Moran, ed., Patronage and Institutions: Science, Technology, and Medicine at the European Court, 1500-1750 (Rochester, N.Y.: Boydell Press, 1991), 5-24; Parrish, American Curiosity, 169-73; Spary, Utopia's Garden, esp. 61-78. 
of seeds to the Virginian but could not accommodate any plants, "as the Ship is greatly thronged with goods." Another Virginia merchant and acquaintance of Custis's offered space for plants, but paying cargo still took precedence. Collinson declined the offer since the freight on board needed to be delivered "to some place out of the way," and he feared that the plants would suffer from a delayed delivery. Most captains were reluctant to accept biocargo, especially live plants or animals that put demands on a vessel's limited supply of space and water far out of proportion to the profit they promised. ${ }^{14}$

Particularly for those British colonial naturalists who were not substantial planters, finding a captain willing to take a shipment of plants or other natural curiosities posed a significant challenge. In 1705 the South Carolina clergyman Joseph Lord confessed to Petiver that he was "at some loss, at present, how to get any thing sent to you, liveing my self at so great a distance from Charlstown, \& haveing little or no acquaintance with any Seafareing men that use to go to London." Living far from South Carolina's port and being personally unknown to the local ship captains, Lord struggled to find passage for his shipments of Carolinan nature. As the naturalist Mark Catesby told an English correspondent in 1722, "it's no small favour from a master to secure a Single box or parcel" on board a vessel bound for London. To sweeten the deal Catesby gave the captain a tub of Carolina plants to ensure the safe passage of the rest of his botanical cargo. ${ }^{15}$

Whereas Catesby used gifts to entice cooperation from ship captains, a wealthy planter such as Custis or well-connected London merchant such as Collinson relied on his long-standing commercial ties to facilitate the transport of specimens. Custis frequently urged his English correspondents to send seeds and specimens on ships belonging to the merchants who handled his yearly tobacco consignment. The captains employed by these men, he believed, would take greater care with his plants and seeds. Though Collinson agreed that commercial relationships could be used to leverage cooperation from captains, he preferred to send specimens with captains employed by his close friend and fellow Quaker John Hanbury, a prominent

14. John Custis to Peter Collinson, [July 3, 1735], and Collinson to Custis, October 20, 1741, in Swem, "Brothers of the Spade," 44 and 94, respectively.

15. Joseph Lord to James Petiver, April 10, 1705, Sloane 4064, f. 69, British Library; Catesby is quoted in David R. Brigham, "Mark Catesby and the Patronage of Natural History," in Amy R. W. Meyers and Margaret Beck Pritchard, eds., Empire's Nature: Mark Catesby's Nerw World Vision (Chapel Hill: University of North Carolina Press, 1998), 102, 107. 
merchant in the Virginia tobacco trade. In 1741 Collinson explained the safe arrival of a shipment of plants sent to Custis by noting that "Captain Harding Had the strictest Charge from Mr. Hanburry in my Hearing that what Ever He did to take Care of your plants \& Deliver them the very first Opportunity - so I would hope he paid some Regard to his Masters Orders." Collinson trusted that a direct order from his employer would give Captain Harding the necessary incentive to take special care of the naturalist's botanical cargo. Such personal and commercial ties might increase a shipment's odds of success, but both naturalists recognized that once out of sight, captains were largely beyond their control. ${ }^{16}$

Naturalists in French North America similarly looked to place reliable surrogates aboard the ships that carried their specimens across the Atlantic. In 1750, for example, the royal physician Jean-François Gaultier wrote to Réaumur from Quebec to inform him that "I have charged M. Fesneau surgeon major aboard the ship La parfaite union with the collection of birds that I am sending you. This young man seemed charmed to have the occasion to oblige you, and you can ask him for several pieces of natural history, he seems to have a taste for this science." Yet French North American naturalists such as Gaultier were far less reliant on middlemen such as Fesneau than their English counterparts. Gaultier, after all, was also a corresponding member of the Académie; he was a product of a concerted effort to integrate scientific research into the sinews of France's Atlantic Empire, and the beneficiary of a synergy between science and state that gave him access to military and administrative networks that significantly eased his efforts to transport scientific specimens across the Atlantic and on to Paris. ${ }^{17}$

The transport of scientific specimens from New France to old was shaped by a larger scientific culture that translated scientific activity into service to the state and Crown, a product of the unique history and influence of the Paris-based Académie Royale des Sciences. Part of a larger initiative to centralize cultural production in seventeenth-century France initiated by Jean-Baptiste Colbert, the founding of the Académie aimed both to reorganize scientific practice in France and to create an arbiter of scientific legitimacy in France and the wider world. Members of the Académie selfconsciously served two masters, a relationship eloquently captured by the images of Minerva and Louis XIV figured on a medal struck on the occasion

16. Peter Collinson to John Custis, February 2, 1741, 86; Custis to Collinson, [Summer] 1741, and Custis to Collinson, [April 20, 1741], in Swem, "Brothers of the Spade," 86, 91, and 89, respectively.

17. Gaultier to Réaumur, n.d., in Vallée, "Cinq lettres," 37. 
of the Académie's first meeting in 1666. Though an exhortation to enrich France and its king often failed to translate into tangible technological advancements, both a "utilitarian bent" in the early Académie and a growing sense of the inadequacy of individual curiosity conflated service to the Académie, to the state, and to the Crown. ${ }^{18}$

The Académie, its members, and its activities were integrated into the French state, as it was officially protected by Colbert, then secretary of the Marine and minister of finances. This close connection between the French naval administration and the Académie continued under the Phélypeaux family in the eighteenth century, when father and son Louis and Jerome Phélypeaux (both the comte de Pontchartrain) and Jerome's son JeanFrédéric Phélypeaux (comte de Maurepas) served as secretaries of the Marine and protector of the Académie. The integration of colonial and naval administration and scientific research in the Atlantic world also manifested itself in the activities and careers of lower-level administrators. For example, Roland-Michel Barrin de La Galissonière, governor of New France between 1747 and 1749 and collaborator with Duhamel du Monceau, was also a member of the Académie Royale des Sciences and a founding member of the Académie of the Marine, an institution focused specifically on discussing and improving maritime sciences, including shipbuilding and navigation. ${ }^{19}$

18. Roger Hahn, The Anatomy of a Scientific Institution: The Paris Academy of Sciences, 1666-1803 (Berkeley: University of California Press, 1971), 4, 11 ("utilitarian bent"), 46-47, 58-60. See also Charles Coulton Gillespie, Science and Polity in France: The End of the Old Regime (Princeton: Princeton University Press, 2004). For a discussion of utilitarian science in ancien régime France, see Robin Briggs, "The Académie Royale des Sciences and the Pursuit of Utility," Past and Present 131 (1991): 38-88; Emma Spary, “Peaches Which the Patriarchs Lacked': Natural History, Natural Resources, and the Natural Economy in France," History of Political Economy 35 (2003): 15-16.

19. François Régourd, "Sciences et colonisation sous l'Ancien Régime: Le cas de la Guyane et des Antilles françaises, XVIIe-XVIIIe siècles" (thesis, Université Michel de Montaigne Bordeaux 3, 2000), 258-70. On Colbert's role in the founding of the Académie Royale des Sciences, see Alice Stroup, A Company of Scientists: Botany, Patronage, and Community at the Seventeenth-Century Parisian Royal Academy of Sciences (Berkeley: University of California Press, 1990), 47-51; Hahn, Anatomy of a Scientific Institution, esp. 8-19. On his role as secretary of the Marine, see Michel Vergé-Franceschi, La Marine française au XVIIIe siècle: Guerres, administration, exploration (Paris: SEDES, 1996), esp. 33-42. For a discussion of the influence of the Phélypeaux family on the Marine, see ibid., 57-102. For a study of the influence of Louis Phélypeaux as protector of the Académie, see Stroup, Company of Scientists, esp. 13-26, 56-60; For a study of Jean-Frédéric's role as protector, see 
This integration of the Académie into the administrative apparatus of the French Atlantic empire progressively gave rise to what the historians François Regourd and James McClellan have called a "colonial machine," a long-term process that centered the scientific networks of the French Atlantic on Paris and made service to the state and subordination to the Académie Royale des Sciences defining features of scientific practice in the French Atlantic world. The emergence of the colonial machine in the late seventeenth century had an almost immediate effect on the collection and transport of natural history specimens between French colonies and Paris. Among the earliest manifestations of the colonial machine was the organization of scientific expeditions that collected astronomical data and, often tangentially at first, botanical and zoological specimens. Traveling naturalists such as the astronomer Jean Richer and the botanist Charles Plumier proved to be an effective means of extending the reach of the Académie and expanding the scale of its members' research projects. By the early eighteenth century, however, efforts to secure reliable supplies of flora and fauna from French North America led to the cultivation of long-term relationships with royal physicians in French colonies and the settlement of official corresponding members of the Académie. In 1700 Michel Sarrazin became both royal physician in New France and the first corresponding member of the Académie in North America; the number of North American plants and animals transported to France as scientific specimens increased immediately and dramatically. Sarrazin's placement created a new node in the Académie's Atlantic networks that was maintained, after his death, by the subsequent royal physician, Jean-François Gaultier. In New Orleans royal physicians and apothecaries such as Jean Prat and Alexandre Vielle were similarly integrated into the research of individual academicians. ${ }^{20}$

Michel Lamontagne, "L'influence de Maurepas sur les sciences: Le botaniste Jean Prat à La Nouvelle Orléans, 1735-1746," Revue d'Histoire des Sciences 49, no. 1 (1996): 113-24. See also Sara E. Chapman, Private Ambition and Political Alliances in Louis XIV's Government: The Phelypeaux de Pontchartrain Family 1650-1715 (Rochester, N.Y.: University of Rochester Press, 2004). On Galissonière, see Roland Lamontagne, La Galissonière et le Canada (Montreal: Presses de l'Université de Montréal, 1962), 68-75.

20. On the "colonial machine" see James McClellan III and François Regourd, "The Colonial Machine: French Science and Colonization in the Ancien Régime," Osiris 15 (2000): 31-50, and The Colonial Machine: French Science and Overseas Expansion in the Old Regime (Turnhout, Belgium: Brepols, 2011). Regourd, "Capitale savante, capitale coloniale." On Atlantic astronomy, see Jordan Kellman, "Discovery and Enlightenment at Sea: Maritime Exploration and Observation in the 18th-Century French Scientific Community" (Ph.D. diss., Princeton University, 
As colonial administrators, physicians, and naturalists affiliated with the Académie, collectors such as Gaultier, Sarrazin, and Prat were able to draw on networks that stretched from the interior of North America to Paris. They used these networks to transport not only their own specimens, but also those entrusted to them or other colonial administrators by amateur naturalists seeking to ingratiate themselves with French Atlantic administrators. They were often aided, as well, by intendants who, driven as much by their own interest in natural history as their desire to please their metropolitan superiors, facilitated the transport of specimens on the royal ships that otherwise carried administrators, missionaries, soldiers, or official correspondence. Writing from Quebec in October 1743, for example, the intendant of New France, Gilles Hocquart, wrote to the naval secretary, Maurepas, advising him that he was sending nine cases of plants along with varied administrative correspondence on the Rubis, a warship of five hundred to seven hundred tons that made regular trips between France and New France during the early 1740s as a key component of France's Atlantic administrative networks. Hocquart similarly sent two cases of plants to France in 1745 aboard the Castor. Built in New France, the Castor was also one of the king's ships, a royal frigate that traveled between Quebec and Rochefort before being captured by the English. Royal frigates also carried botanical specimens and samples of commodities produced from them to France from Louisiana. The use of such ships would have made superfluous the sorts of dockside negotiations common for naturalists such as Bartram and Collinson. The captain of the Castor, for example, was a paid employee of the state; Sieur André Dubois was a salaried lieutenant de frégate ordered to take command of the recently built ship, to carry cargo to France, and to escort merchants' ships during the passage. A commander's being required to transport specimens did not, of course, guarantee that he would give the high level of care desired by French naturalists, but it did open access to ship's holds and, judging from a noticeable lack of complaints in surviving documents (where few were otherwise shy about their opinions), ensure

1998), esp. 80-176. On Sarrazin and Gaultier see Arthur Vallée, Un biologiste canadien: Michel Sarrazin, 1659-1735: Sa vie, ses travaux et son temps (Quebec: Quotidien Levis, 1927), and Jacques Rousseau, "Michel Sarrazin, Jean-François Gaulthier et l'étude prélinnéene de la flore canadienne," in Les botanistes français en Amérique du Nord avant 1850 (Paris: Editions du Centre National de la Recherche Scientifique, 1957), 149-57. On Prat and New Orleans, see Lamontagne, "L'influence de Maurepas sur les sciences.” 
a minimum standard of attention that preserved many specimens during transport. $^{21}$

Though merchant ships still frequently carried scientific specimens, the availability of royal vessels transformed the social practices of specimen transport in the French Atlantic world. The transport of natural history specimens from the interior of the North American continent and across the Atlantic Ocean was purposefully grafted onto administrative and military networks that bound the disparate colonies and settlements that stretched across North America from Acadia to New Orleans. In 1707, for example, Secretary of the Marine Louis Phélypeaux wrote to New France's co-intendant, AntoineDenis Raudot, a supporter of Sarrazin's work, ordering the "Officers of the King . . . to receive these cases of plants into their buildings without difficulty, to have them placed in an appropriate place where they will be preserved and to send them to my address." From the interior of the continent came specimens from vast networks of missionaries, colonists, and military officials. Pehr Kalm, a student of Carl Linnaeus who traveled in North America between 1748 and 1751, wrote that he was impressed by the collection of soil specimens that Gaultier was able to show him in Quebec, products of networks that brought specimens from all over the continent. Amateur naturalists who willingly surrendered their specimens to the care of colonial administrators were similarly able to rely on royal ships to carry the fruits of their labor (figure 1). These often overlooked collectors could also be compensated for expenses accrued while transporting the specimens to port cities such as Quebec and New Orleans. ${ }^{22}$

21. CAOM, C11C, vol. 50, f. 70 (the Rubis); CAOM, C11C, vol. 84, f. 168 (the Castor). On the importance of patronage see Kathryn A. Young, "Crown Agent-Canadian Correspondent: Michel Sarrazin and the Académie Royale des Sciences, 1697-1734," French Historical Studies 18, no. 2 (1993): 420-22; Giraud, History of French Louisiana, 217-19. For a description of the royal frigates that traveled between France and Quebec, see Gilles Proulx, Between France and New France: Life aboard the Tall Sailing Ships (Toronto: Dundurn Press, 1984), 18. The royal frigate La Mégère transported cotton and candles produced from a local plant from Louisiana in March 1748, for example; see CAOM, C13A, vol. 32, ff. 16566. For a discussion of ranks and pay in the French navy, see Vergé-Franceschi, $L a$ Marine française au XVIIIe siècle, 173-216. For a broader discussion of the crew aboard the royal ships that traveled to North America, see Proulx, Between France and New France, 81-99.

22. CAOM, C11G, vol. 2, f. 104-104v ("Officers of the King”); Pehr Kalm, Voyage de Pebr Kalm au Canada en 1749, ed. and trans. Jacques Rousseau and Guy Béthune (Montreal: Pierre Tisseyre, 1977), 314-15, 405, 408-10; CAOM, C11A, 


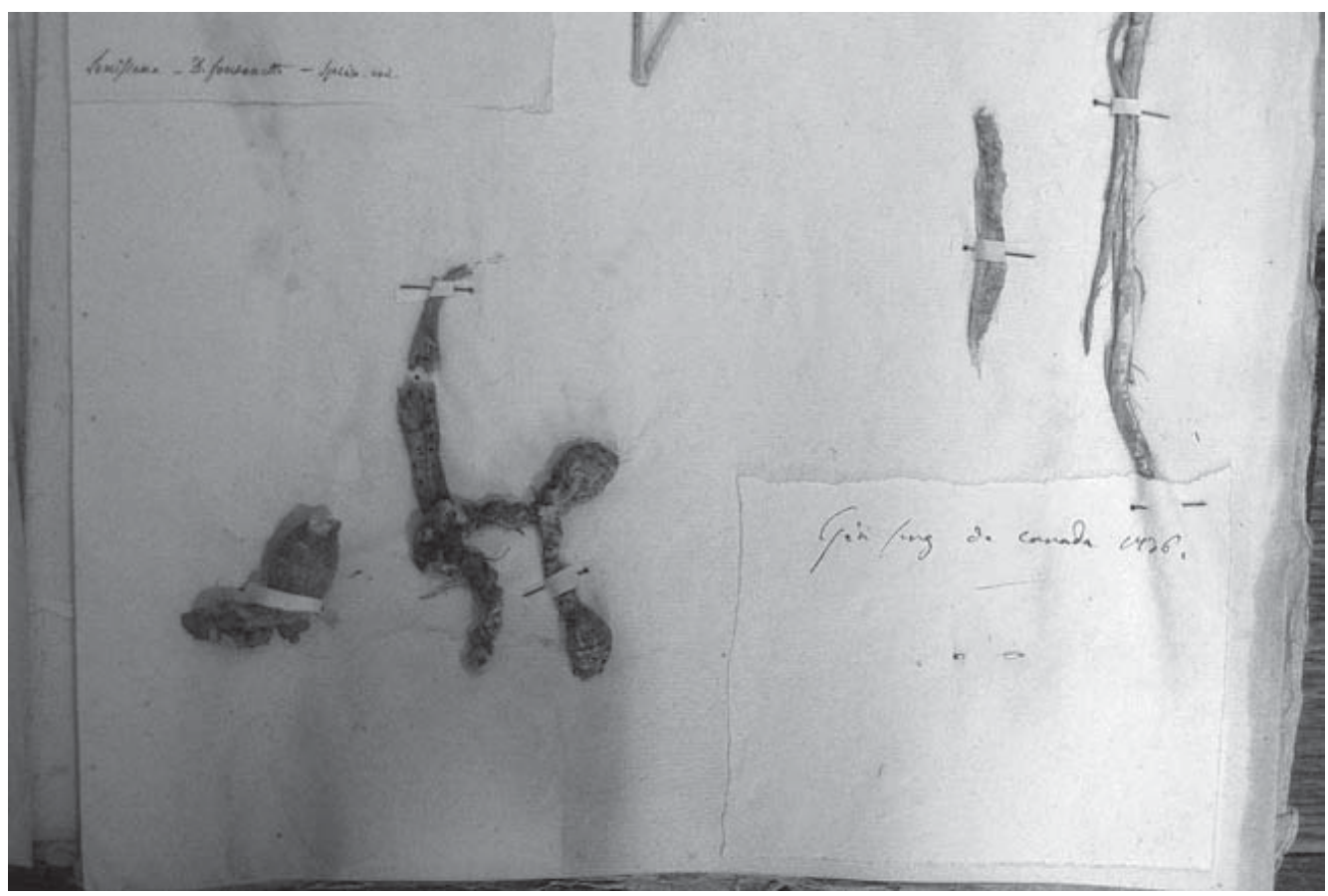

Figure 1. The trained naturalists in Quebec and New Orleans received specimens from deep in the interior of the continent, often through administrative or military channels. These are two specimens of American ginseng (Panax quinquefolius) probably collected by amateur naturalists and sent from Louisiana and New France to Paris in the first half of the eighteenth century. Herbier d'Antoine Laurent de Jussieu, Laboratoire de Phanérogamie, Muséum National d'Histoire Naturelle, Paris.

Yet there were clear limits to the reach of a colonial machine that remained continually overstretched. Naturalists in Louisiana had a particularly difficult time profiting from the partnership between the Académie and the Marine, where historians have convincingly argued that New Orleans remained relatively isolated from Atlantic circuits of cultural and commercial exchange, which forced a reliance on a broader range of transimperial and multiethnic networks. Colonial naturalists in New Orleans therefore faced many of the same challenges as amateur naturalists and collectors in the Anglo-Atlantic world and were far more reliant on merchant

vol. 70, f. 125; vol. 72, f. 174 (payment for transport expenses). For an example of French naturalists placing specimens aboard a merchant ship, see CAOM, C11C, vol. 94, ff. 44-45. Payment to merchants for this sort of service often remained theoretical, however. See J. F. Bosher, "Success and Failure in Trade to New France, 1660-1760,” French Historical Studies 15, no. 3 (1998): 444-61. 
shipping than their counterparts in Quebec. Jean Prat wrote to his patron, Bernard de Jussieu, from New Orleans in 1737 to request that "the commandants of both merchant and royal vessels had orders from the minister to accept and to take care of all of the plants that I give them for the Jardin du Roi." Both Prat and amateur collectors therefore sought alternative avenues to profit from their natural history work and to ensure the safe transport of their specimens across the Atlantic. Antoine-Simon Le Page du Pratz wrote, for example, that he gave samples of over three hundred medicinal plants to the Compagnie des Indes for transport to France and the Jardin du Roi. Prat himself similarly sought to build his own network when he felt that the official networks of the French Marine were lacking. $\mathrm{He}$ transported specimens with missionaries and surgeons, and he posted them to a colleague in Rochefort who would look after his specimens until called for by metropolitan administrators. His Canadian counterpart, JeanFrançois Gaultier, took similar precautions, addressing his specimens to a colleague in La Rochelle when he feared that they might otherwise not make it to their final destination. The limits of the "colonial machine" were apparent to colonial naturalists in Quebec and especially New Orleans who continued to take precautions and, where needed, arrange alternative methods of transport. ${ }^{23}$

Both English and French naturalists sought means to regulate the social environments through which their specimens traveled, a goal born of their

23. Prat is quoted in Roland Lamontagne, "Le dossier biographique de Jean Prat," Revue d'Histoire de l'Amérique Française 16, no. 2 (1962): 223 ("commandants of both"); Antoine-Simon Page du Pratz, Histoire de la Louisiane, 3 vols. (Paris: Bure, Delaguette, Lambert, 1758), 2:2; Prat to Jussieu, July 13, 1735, in Roland Lamontagne, "Jean Prat, correspondant de Bernard de Jussieu," Rapport des Archives du Québec, 41 (1963): 126 (Rochefort connection); Gaultier to Réaumur, September 3, 1750, in Vallée, "Cinq lettres," 38. On the overstretched colonial machine and, more broadly, France's "imperial overstretch," see Kenneth J. Banks, "Communication and 'Imperial Overstretch': Lessons from the Eighteenth-Century French Atlantic," French Colonial History 6 (2005): 17-32; James Stewart Pritchard, In Search of Empire: The French in the Americas, 1670-1730 (Cambridge: Cambridge University Press, 2004). On Louisiana see Kenneth J. Banks, Chasing Empire across the Sea: Communications and the State in the French Atlantic, 1713-1763 (Montreal: McGill-Queen's University Press, 2002), 84-87, 184-94. For a discussion of British naturalists' desire for state-sponsored science on the French model, see Richard Drayton, Nature's Government: Science, Imperial Britain, and the 'Improvement' of the World (New Haven: Yale University Press, 2000), 43; Richard Drayton, "A l'école des Français: Les sciences et le deuxième empire britannique (1780-1830)," Revue Française d'Histoire d'Outre-mer 1 (1999): 91-118. 
desire for collaborators whose commitment mirrored their own and their fear of those whose inattention could have disastrous implications for their botanical and zoological research. Yet the strategies embraced by French and English naturalists in the eighteenth-century Atlantic world was split on distinctly national lines, inspired, as they were, by the different cultures of the Royal Society of London and the Académie Royale des Sciences and the different social resources at their disposal. These sizable differences masked a reliance on shared material practices employed to produce natural history specimens that could survive the trip and to create shipboard ecosystems that would protect and preserve them.

\section{THE MATERIAL PRACTICES OF SPECIMEN TRANSPORT IN THE}

\section{EIGHTEENTH-CENTURY ATLANTIC WORLD}

Whereas the social practices of specimen transport highlight the structural differences between French and British networks of natural history, the material practices used to produce and transport specimens demonstrate striking similarities between the two. In part this reflects the universalizing tendencies of Enlightenment science, in which naturalists of all nationalities strove to produce and procure fungible specimens. Yet the universalism of eighteenth-century science was often more ideal than real. To understand the fundamental similarities between French and British material practices, the physical spaces of natural history rather than abstract ideas provide the best explanation. The natural environment of the ship and the challenges this environment created for delicate specimens varied little with the flag flown. Ships were ecosystems onto themselves, complete with predators, microclimates, and symbiotic relationships. Therefore naturalists, whether French or British, had to develop material practices that could protect their biocargo during weeks at sea. For if the settlement of correspondents in Quebec or Philadelphia ensured a regular supply of New World naturalia and a much clearer sense of provenance, it did little - in and of itself - to ensure that those natural history specimens that traveled to Paris and London arrived in the condition necessary to be of use to metropolitan naturalists. The material objects received by European naturalists, to a large degree, determined the natural knowledge they produced.

Naturalists characterized the natural environment of ships as full of potential pests that posed a threat to their precious cargo. Their letters frequently chronicled the trials and tribulations of the trans-Atlantic exchange of natural curiosities. Such problems could range from the spectacular, such as hurricanes and capsized vessels, to the mundane, such as mildew and insects. Live plants and animals were particularly vulnerable to 
the many pests and hazards on board eighteenth-century vessels. A pot of plants, for example, might be torn to bits by dogs, eaten by mice, scratched by cats, or become the new home for "Two Nests of young Callow Ratts." At least occasionally, the threat to specimens' survival was itself packed on board by a naturalist. Though there was no mention of any damage, one has to question the wisdom of sending caterpillars that had recently ravaged the farms of New France in the same shipment as specimens of "plants, nuts, [and] fruits of the cotonnier." If such dangers could not be wholly avoided, naturalists learned to limit their effects. ${ }^{24}$

Naturalists developed a keen awareness (produced more often by disappointment than by design) of the many microclimates aboard the ships they entrusted with their specimens. The precise placement of naturalia within the vessel often determined whether they would survive the voyage. Although small by modern standards, the eighteenth-century ship provided multiple microclimates that varied in terms of light, fresh air, heat, and exposure to salt spray. The constant sloshing and spraying of saltwater could quickly kill any plants left unprotected on the vessel's deck, but those placed safely below would slowly perish without exposure to sunlight. Duhamel du Monceau warned that live trees "must be placed, as much as possible, in open air \& at the top of the vessel." He cautioned, however, "In great gusts of winds, great colds, excessive heats, \& even stubborn rains, it is necessary to take them inside, or at least cover them with their hood or another shelter." While the lack of sunlight posed no problems for seeds, naturalists worried about the effects of the heat and "putrid penetrating steam" belowdecks. The choicest spot was in the captain's personal cabin, for here specimens and plants could be kept dry, receive sunlight from the stern windows, and be protected from many of the ship's hazards. Whether the naturalist had the "privilege of the cabin" (the promise on the part of the captain to store natural curiosities in his personal cabin) could determine naturalists' decisions about to whom they would entrust their cargo. Such promises, however, were not always kept. Although Bartram was personally assured by the shipmaster that a box of butterflies would be stored in his cabin, it instead made the crossing in the lazaretto (ship's storeroom), under a leaky bag of salt that nearly ruined the collection. As Bartram later reminded his

24. John Custis to Robert Cary, 1726 (dogs), and Peter Collinson to Custis, February 6, 1743 (mice), in Swem, "Brothers of the Spade," 37-38 and 100, respectively; Collinson to John Bartram, January 1736 (cats), and Collinson to Bartram, April 12, 1739 (rats), in Correspondence of John Bartram, 14 and 118, respectively; CAOM, C11C, vol. 80, f. 274 (caterpillars from New France). 
correspondent, in such situations there was little the naturalist could do but “exercise patience."25

With patience and time, naturalists developed an environmental science of ships. At the beginning of the eighteenth century the avid English collector Petiver instructed correspondents that when transporting seeds from America, they "need[ed] no other care but to be sent whole." Yet by the middle of the century, experience had proved this often was not the case. Seeds, particularly when confined in "the damp and putrid heat of the [ship's] hold," often lost their vegetative quality and failed to germinate when planted. Naturalists learned, therefore, that simply sending seeds whole would not guarantee success. Although such knowledge was most broadly disseminated through publications such as Duhamel du Monceau's Avis (1752) and Ellis's Directions (1770), it was based on decades of experience. Duhamel du Monceau, Ellis, and their colonial counterparts refined their practices through correspondence and exchanges that stretched over years, sometimes decades. When a shipment arrived in either particularly good or particularly poor condition, naturalists made note of the method by which it was packed and where on the ship it was carried. In this iterative fashion, naturalists perfected the practices that best protected delicate seeds and specimens during transport. ${ }^{26}$

In the case of seeds, naturalists' primary concern was to control the moisture to which they were exposed; too little moisture would dry out the seeds, whereas too much risked rotting or premature germination. Because of such concerns, most eighteenth-century naturalists ignored Petiver's advice and instead recommended special attention to the manner in which seeds were packed. In the 1750s and 1760s Ellis undertook a series of experiments on acorns to determine the best method of seed preservation. On this basis he

25. Duhamel du Monceau, Avis, 28; Ellis, Directions, 15; Peter Collinson to John Custis, December 15, 1735, and Collinson to Custis, January 31, 1740, in "Forget Not Mee and My Garden. ..": Selected Letters, 1725-1768, of Peter Collinson, F.R.S., ed. Alan W. Armstrong (Philadelphia: American Philosophical Society, 2002), 37 and 81, respectively (privilege of the cabin); Collinson to John Bartram, December 20, 1737, and Bartram to Collinson, May 1738, in Correspondence of John Bartram, 74 and 88, respectively (butterflies).

26. James Petiver, Brief Directions for the Easie Making and Preserving Collections for James Petiver, Fellow of the Royall Society London (London, 1709), 1; Ellis, Directions, 14-15 ("putrid heat"). For naturalists noting shipment packing methods, see Peter Collinson to John Custis, December 26, 1738, in Swem, "Brothers of the Spade," 72; Custis to Collinson, [August 12], 1739, in Letterbook of John Custis, 204. 
recommended coating seeds in beeswax for long voyages to prevent them from losing "their vegetating power." For shorter voyages, such as those to England from the West Indies and southern mainland colonies, Ellis advised collectors to divide a wooden box "into several square partitions," fill each with a mixture of dry "loamy earth and cut moss," and securely nail the box shut (figure 2). Similarly, Duhamel du Monceau recommended closed and dry cases to keep the ship's air and moisture from affecting the quality of the seed. The Avis counseled, for example, that "The first of these methods is to put them in earth that is almost dried and well mixed in a barrel or in a well-sealed box. We have received some nuts and seeds of the Bonduc from Canada which arrived all germinated and which have all succeeded well." If suitably packed, even seeds that germinated during transport might successfully be planted in Europe. ${ }^{27}$

As it was with seeds, the primary concern with live plants was keeping them in a sort of equilibrium within shipboard environments. Naturalists often worried about the suitability of the season in which plants made their trans-Atlantic crossing, fearing extremes of both hot and cold. Yet in this British naturalists were at the mercy of the rhythms of commerce, whereas their French counterparts were often subject to the seasonal shipments of administrative correspondence. While Collinson might wish that Virginiabound ships left London at the beginning of October rather than "on the other side of Christmas," he also knew that the rhythms of the tobacco trade determined their schedule. Naturalists instead learned to minimize the damage by, whenever possible, shipping specimens appropriate for the season. Over time, this knowledge became more specialized, varying with the precise nature of the cargo and the port of origin. One naturalist recom-

27. Ellis, Directions, 3-5, 12; Peter Collinson to John Bartram, March 1, 1735, in Collinson, Forget Not Mee, 30; Collinson to John Custis, January 25, 1739, in Swem, "Brothers of the Spade," 76; John Ellis, "An Account of Some Experiments Relating to the Preservation of Seeds: In Two Letters to the Right Honourable the Earl of Macclesfield, President of the Royal Society," Philosophical Transactions 51 (1759-60): 206-15; John Ellis, "A Letter from John Ellis, Esquire, F.R.S., to the President, on the Success of His Experiments for Preserving Acorns for a Whole Year without Planting Them, so as to be in a State Fit for Vegetation, with a View to Bring Over Some of the Most Valuable Seeds from the East Indies," Philosophical Transactions 58 (1768): 75-79; entry for March 10, 1768, Journal Book of Scientific Meetings, Collections from the Royal Society, 1660-1800 vol. 26, 478-80; de La Galissonière and Duhamel du Monceau, Avis pour le transport, 57 ("first of these methods"). For more on cases, also see Allain, Voyages et Survie, chap. 3, and Yannick Romieux, "Le transport maritime des plantes au XVIIIe siècle," Revue d'Histoire de la Pharmacie 92, no. 343 (2004): 410-13. 


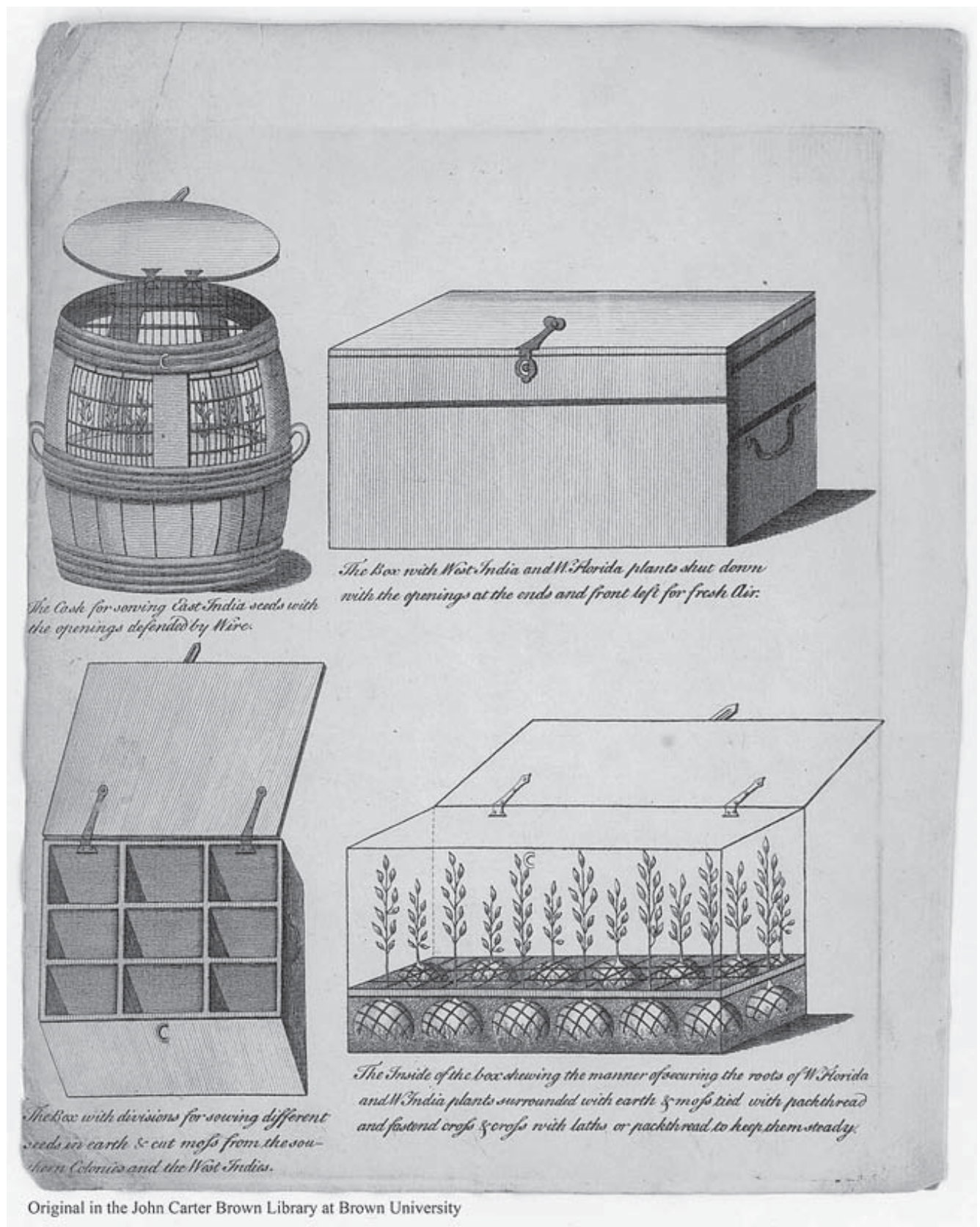

Figure 2. On the basis of decades of correspondence with naturalists in British plantation societies, John Ellis recommended specialized containers for transporting seeds and specimens. For transporting seeds, Ellis advised a "Box with divisions for sowing different seeds in earth \& cut moss" (lower left). He similarly recommended a combination of earth and moss to secure plants shipped from West Florida and the West Indies in a box with openings for fresh air (top and bottom right). John Ellis, Directions for Bringing Over Seeds and Plants, from the East-Indies and Other Distant Countries, in a State of Vegetation... (London, 1770). Courtesy of the John Carter Brown Library at Brown University. 
mended, for example, that most plants from West Florida or the West Indies be sent to Europe on the spring ships-"otherwise they will be destroyed by the cold of this latitude"-but that evergreens were best sent during winter months "while their juices are inactive, so as to arrive here before the heats come on." 28

Despite the many difficulties they presented, plants were nonetheless far easier to transport than animals. Michel Sarrazin suggested that his Parisian patrons simply observe French river otters and read his descriptions of Canadian varieties, rather than be disappointed by what he would be able to send them. Jean-François Gaultier reported that his collectors were the weak link in his efforts to provide properly preserved Canadian animal specimens. In 1754 he wrote, "A stuffed seal skin has already arrived with its head [intact]. But the entire thing was in such bad condition that I could not imagine that I could send it to you." He similarly explained that his failure to produce a porcupine specimen was the result of aboriginal collectors who damaged and discarded the skin as they consumed the animal while "tormented by hunger." Naturalists occasionally attempted to transport living animals, but this was an even more challenging undertaking. Bartram, for example, tried repeatedly to send tortoises for his noble patron's garden, but few survived the trans-Atlantic voyage. Those sent without food probably died of starvation, while others were washed overboard or stolen by sailors (perhaps similarly motivated by a lack of food?). Even naturalists who accompanied their specimens could not guarantee that they would survive the crossing. Sloane took a tamed seven-foot yellow snake, an "a guana," and an alligator with him on the return voyage from Jamaica. Unfortunately for Sloane, the snake was shot when it escaped its earthen-jar home, the "a guana" accidentally jumped overboard when startled by a sailor, and the alligator died of natural causes, despite being kept in a tub of saltwater in the forecastle of the ship. "Thus I lost, by this time of the Voyage, all my live Creatures, and so it happens to most People, who lose their strange live Animals for want of proper Air, Food, or Shelter." ${ }^{29}$

28. Peter Collinson to John Custis, November 12, 1736, in Swem, "Brothers of the Spade," 51; Ellis, Directions, 9 (seasons for shipping plants).

29. Sarrazin to Jean-Paul Bignon, April 2, 1727, in Vallée, Biologiste canadien, 232; Gaultier to Réaumur, October 6, 1754, in Vallée, "Cinq lettres," 41; Peter Collinson to John Bartram, January 17, 1736, Collinson to Bartram, February 3, 1736, Collinson to Bartram, June 1, 1736, and Collinson to Bartram, March 14, 1737, in Correspondence of John Bartram, 14, 17, 28, and 42, respectively; Hans Sloane, A Voyage to the Islands Madera, Barbadoes, Nieves, St. Christophers and Jamaica, with the Natural History . . of the last of those Islands . . , 2 vols. (London $1707,1725), 2: 346-47$. For similar difficulties transporting live animals from the 
Most of the animals that were transported across the Atlantic as scientific specimens, however, were dead when they were shipped. So infrequently were live animals transported that printed instructions typically omitted this category of specimen altogether. When Duhamel's text on the transport of plants was joined to a larger text by Etienne-François Turgot that dealt with the collection and transport of quadrupeds, birds, fish, shells, and other naturalia, instructions included the proper preparation of skins and stuffed specimens but provided no guidance for the transport of live animals. Whereas butterflies were typically pinned and plants pressed, bird, fish, and other animal specimens were most often transported across the Atlantic preserved in brandy, wine, or rum. ${ }^{30}$ Gaultier's description of a 1753 shipment to the academician Réaumur captures the miscellany contained in the barrels of liquor shipped across the Atlantic: "I have loaded on the vessel the Saint-Thomas a simple barrel filled with gualdive or tafia with the following animals 1) a wild dog brought from the Hurons, a nation of sauvages, 2) a red fox; this species is tamed at Quebec 3) a hare. This is one of the hare that becomes all white during the winter, and in the summer they recover their gray colour. 4) a bird of prey that was taken during the winter in Quebec, it eats pigeons and other birds." Hoping to ensure that the identity of these specimens would remain fixed during the transport, Gaultier added, "I have put a label on each piece, so that it will be easy to recognize them." Submerging animals in alcohol preserved morphological features necessary for the identification of specimens, but some collectors found the results less visually appealing than specimens that had been dried or embalmed. Réaumur, however, suggested that sending birds in liquor preserved the shape and color of specimens much better than stuffing and drying. His Canadian correspondent Gaultier similarly wanted to make sure that "eaude-vie does not, by its force, make the scale of fish fall off or make them

Dutch East Indies, see Cook, Matters of Exchange, 326; Louis Robbins, Elephant Slaves and Pampered Parrots: Exotic Animals in Eighteenth-Century Paris (Baltimore: Johns Hopkins University Press, 2002), 12.

30. Robbins, Elephant Slaves, 19; E. F. Turgot, Mémoire instructif sur la manière de rassembler, de préparer, de conserver, et d'envoyer les diverses curiosités d'bistoire naturelle (Paris, 1758). Preserving animals in alcohol might have added to the many dangers facing specimens at sea. The historian Raymond Phineas Stearns speculated that "the contents of an untold number of vials and wide-mouthed bottles filled with 'fleshy' insects, small animals, or fishes preserved in brandy or other spirits were consumed by sailors unconcerned with the protein content." Stearns, "James Petiver: Promoter of Natural Science, c. 1663-1718," Proceedings of the American Antiquarian Society 62 (October 1952): 290. 




Figure 3. Herbarium specimens made American plants portable and facilitated comparative study in metropolitan centers such as Paris and London. Samples of this plant, Osmunda canadensis, were sent by Michel Sarrazin to Paris in 1700 and 1705. Herbier de Vaillant, Laboratoire de Phanérogamie, Muséum National d'Histoire Naturelle, Paris. 
close up." Yet for those collectors who wished to display exotic birds and other animals in cabinets, stuffed, embalmed, or dried specimens were more desirable. $^{31}$

Properly packed specimens could limit the effects of the ship's microclimates and many dangers. In a few cases, Atlantic naturalists employed tried and tested methods such as drying plants to produce the sort of herbarium specimens that had circulated throughout Europe since the sixteenth century (figure 3). Rarely, however, did the material practices long relied on in Europe protect specimens crossing the Atlantic. Some lessons were quickly learned, such as that pots and glass containers were too liable to shatter or crack during transport, whereas wooden boxes, barrels, and baskets survived the voyage intact. Other lessons evolved more slowly. While naturalists agreed that plants needed to remain moist despite infrequent watering, which packing material best achieved this remained a matter of debate. Ellis, for example, recommended that the bottom of the container be covered with two or three inches of wet moss "or, if that cannot be got, some very rotten wood or decayed leaves, and then fresh loamy earth, about twelve inches deep." Other naturalists tailored their recommendations to the type of plant, advising that shrubs be wrapped in damp moss but that milky plants be placed in sand and dry moss. A well-designed container might also keep out the many animals that inhabited eighteenth-century vessels. Collinson recommended that Bartram "nail a few small Narrow Laths" across the top of a box of plants "to keep the Catts from Scratching It." Wire covers on top of plants might also prevent rats and other vermin from destroying the specimens. Réaumur recommended transporting specimens in wooden barrels to reduce the likelihood of damage from both insects and shipboard turbulence. ${ }^{32}$

31. Gaultier to Réaumur, August 28, 1753, in Vallée, "Cinq lettres," 39 ("I have loaded"), 41 (eau-de-vie); M. de Réaumur and Phil. Hen. Zollman, "Divers Means for Preserving from Corruption Dead Birds, Intended to Be Sent to Remote Countries, So That They May Arrive There in a Good Condition," Philosophical Transactions 45 (1748): 307-11 (birds in liquor); Robert McCracken Peck, "Preserving Nature for Study and Display," in Sue Ann Prince, ed., Stuffing Birds, Pressing Plants, Shaping Knowledge: Natural History in North America, 1730-1860 (Philadelphia: American Philosophical Society, 2003), 13-14; Emma Spary, "Codes of Passion: Natural History Specimens as a Polite Language in Late 18th-Century France," in Hans Erich Bödeker, Peter H. Reill, and Jürgen Schlumbohm, eds., Wissenschaft als kulturelle praxis (Göttingen: Vandenhoeck and Ruprecht, 1999), 105-35.

32. Réaumur and Zollman, "Divers Means for Preserving," 309; John Custis to Robert Cary, 1725, in Swem, "Brothers of the Spade," 37 (wooden containers). Ellis, Directions, 8 ("very rotten wood"); Cook, Matters of Exchange, 325 (milky plants); Peter Collinson to John Bartram, January 1736, in Correspondence of John 
In times of war, naturalists worried more about how a package was addressed than the container in which it was packed. The series of eighteenthcentury wars that pitted France against Britain often interrupted colonial communication and made shipping hazardous. Joseph de Jussieu, brother to the famous Paris-based botanists Bernard and Antoine, passed many of the years that he was collecting plants in South America worrying about the safety of his specimens during the War of Austrian Succession. During the Seven Years' War the South Carolina naturalist and physician Alexander Garden noted that of the twenty-one ships that left the colony in January and February 1757, nineteen had been captured, among "them the two most valuable collections of seeds that ever I could promise or even hope to procure." Naturalists tried to limit the damage of such disruptions by transporting specimens on ships traveling in convoy, sending duplicates, and splitting their collections into multiple lots to be carried by more than one ship. When all else failed, naturalists hoped that the practice of counter-directing packages would prevent their specimens' destruction. The second address on a counter-directed package instructed the enemy's sailors to send the specimens to one of their countrymen in case of capture. Although the ship on which Cadwallader Colden of New York had placed a package of seeds was captured by the French in 1745, he had counter-directed the package to Bernard de Jussieu of the Jardin du Roi in Paris. According to his English correspondent Collinson, "Without that precaution a hundred to one but that they had been thrown into the Sea." Such a strategy, at least occasionally, produced the desired results. During the Seven Years' War Duhamel du Monceau facilitated the return of Carolinian specimens captured by French privateers. These seeds, possibly the same collection Garden worried about in 1757, eventually made it to Ellis in London after first being captured in the Atlantic, next sent to the inspector general in France, and then forwarded to the naturalist and member of the Royal Society Dr. Jan Albert Schlosser in Holland. The system of counter-directing packages was, of course, not foolproof. Other packages were never seen again, perhaps unceremoniously dumped into the ocean or privately sold to collectors. ${ }^{33}$

Bartram, 14 ("Narrow Laths"); Ellis, Directions, 7 (wire covers); Réaumur and Zollman, "Divers Means for Preserving," 309-11 (barrels). On the sixteenth-century history of herbarium specimens, see Brian Ogilvie, The Science of Describing: Natural History in Renaissance Europe (Chicago: University of Chicago Press, 2006), esp. 42-43, 165-75.

33. Neil Safier, "Fruitless Botany: Joseph de Jussieu's South American Odyssey," in Delbourgo and Dew, Science and Empire, 212-13; Alexander Garden to John Ellis, July 6, 1757, in James Edward Smith, ed., A Selection of the Correspondence of 
To combat the more quotidian dangers confronting botanical and zoological specimens, naturalists relied on practical knowledge that accumulated over time. Through trial and error, horticultural technique outpaced scientific theory. When naturalists suggested, for example, that as much of the earth around roots be preserved, they could have had little sense of the complex microbial ecologies that they were preserving and that recent research demonstrates can be essential for the survival of transplanted plants. Even this, however, was no guarantee of success. Collinson asked Bartram to send some more white cedar, as his was in poor shape even "though it has a clod of its own earth about it." Several years later he wrote that plants whose earth had been "shaken from their Roots" were "very unlucky." Daniel Desmarats, gardener to William III of Orange, offered Hans Sloane similar advice before the Englishman set off for Jamaica. Desmarats recommended preserving as much of the surrounding soil as possible and wrapping the root-ball in damp moss. Once plants arrived in Europe, experience taught naturalists and their gardeners that the key to the transplants' viability was the re-creation of their American ecologies as closely as possible. Duhamel du Monceau suggested burying Canadian trees in snow during winter months to replicate the cold climate from which they had come, and an anonymous gardener at the Jardin du Roi in Paris recommended the use of cloches and other techniques to preserve those that had come from warmer climates. Through their material practices, naturalists sought to maintain the specimens' natural equilibrium and preserve as much of the plant's native ecology as possible. ${ }^{34}$

Linnaeus, and Other Naturalists, from the Original Manuscripts, 2 vols. (London, 1821), 1:414; Peter Collinson to Cadwallader Colden, March 30, 1745, in Collinson, "Forget Not Mee," 124; Ellis to Duhamel du Monceau, February 14, May 18, and June 23, 1769, in Spencer Savage, ed., Catalogue of the Manuscripts in the Library of the Linnean Society of London, part 4, Calendar of the Ellis Manuscripts (London, 1948), 72-73; Duhamel du Monceau to Ellis, May 22, 1757, in Gavin de Beer, The Sciences Were Never at War (London: Thomas Nelson and Sons, 1960), 5-23, 210-20; Ellis to Alexander Garden, April 8, 1761, in Smith, Correspondence of Linnaeus, 1:508. Circumstantial evidence suggests that Colden's precaution paid off. In 1746 Réaumur reported that a French privateer captured a New York ship containing a collection of plants counter-directed to Jussieu and that the privateering captain "faithfully" forwarded them to the Jardin du Roi. Jussieu promised he would happily forward the collection to its rightful owner once it arrived in Paris. De Beer, The Sciences Were Never at War, 11 (translation 212).

34. Duhamel du Monceau, Avis, 12; Correspondence of John Bartram, 86 (clod of earth), 229 (shaken from roots); Cook, Matters of Exchange, 325 (Desmarats); "Mémoire instructif pour faire réussir toutes sortes de semences \& plantes étrangeres," MS 1909, Bibliothèque Centrale, Museum National d'Histoire Naturelle, 3 (cloches). 
Replete with insects and microorganisms, shipboard ecosystems threatened to hasten the decay of preserved animals removed from their natural environments. According to Réaumur, "That Part of Natural History . . . which treats of Birds, has remained as yet very imperfect," owing to insufficient preservation practices that only temporarily halted the decay of animal specimens. Naturalists who followed contemporary preservation practices still "had the Mortification to see [specimens] every Day destroyed by ravenous Insects." The academician therefore made improving preservation practices the subject of a series of experiments beginning in the early 1740s. The four methods he recommended were designed to simultaneously facilitate the birds' transport, protect them from insects and decay, and "make them look as if alive." The techniques varied, however, in the skill they required. The simplest solution was to submerge the specimen in brandy; it could then be either transported in liquor or removed from the alcohol and transported in a box filled with straw or chaff. Réaumur's other preservation methods - embalming, drying in an oven, or stuffing the bird's skin with flax, wool, or hay-required considerably more skill. Whichever way the collector preserved the specimen, it needed to be carefully packed with soft materials and in a well-sealed container to survive the trans-Atlantic crossing intact. ${ }^{35}$

The networks in which knowledge of Réaumur's techniques traveled were transnational and porous, especially where they circulated in printed texts or periodicals. Read to the Royal Society of London in the spring of 1748, "Divers Means for Preserving from Corruption Dead Birds, Intended to Be Sent to Remote Countries" was an exact translation of a pamphlet Réaumur had published in French on the subject the previous year. Its reading at the Royal Society and subsequent publication in Pbilosophical Transactions extended the circulation of Réaumur's preservation methods. The French naturalist's knowledge was welcomed in North America as well; portions of

Ellis, Directions, 9, also recommended preserving "as much earth as can be about their roots." For an overview of soil ecology and mutualistic plant-microbe relationships, see E. Toby Kiers and R. Ford Denison, "Sanctions, Cooperation, and the Stability of Plant-Rhizosphere Mutualisms," Annual Review of Ecology Evolution, and Systematics 39 (2008): 215-36, and Bob Schippers, Albert W. Bakker, and Peter A. H. M. Bakker, "Interactions of Deleterious and Beneficial Rhizosphere Microorganisms and the Effect of Cropping Practices," Annual Review of Phytopathology 25 (1987): 339-58.

35. Réaumur and Zollman, "Divers Means for Preserving," 305, 306-17; Paul Lawrence Farber, "The Development of Taxidermy and the History of Ornithology," Isis 68, no. 4 (December 1977): 550-54. 
Réaumur's text were published in Transactions of the American Philosophical Society within two decades. The speed with which texts such as Réaumur's circulated throughout the Atlantic world helps explain the continuity of material practices between French and British networks of natural history. Not only did Atlantic naturalists face the same shipboard environmental challenges, but they also shared a common understanding of how best to prepare specimens for the ship's many microclimates. ${ }^{36}$

As Réaumur understood, the taxonomic and comparative work of metropolitan naturalists was only as good as the specimens they received. The material practices of preservation promoted by European naturalists attempted to regain control over this critical stage in the production of knowledge. By instructing colonial correspondents to pin butterflies, press plants, and submerge small animals in brandy, naturalists aimed to both utilize and erase the geographical advantage of American naturalists by transforming American nature into a series of stable, immutable, and mobile inscriptions that could be transported back to Europe for analysis. Yet, as the trans-Atlantic dispute over the nature of a curious biped amphibian illustrates, this was always an incomplete process. ${ }^{37}$

In 1765 the South Carolina naturalist Garden announced the discovery of a new species, known locally as the "mud iguana." He claimed that the iguana represented a distinct genus, lying somewhere between the Muraena (eels) and the Lacerta (lizards). Ellis and other British naturalists initially scoffed at Garden's characterization, suggesting instead that the unusual two-legged amphibian was the larvae of a common four-legged lizard.

36. Réaumur, Différens moyens d'empêcher de se corrompre les oiseaux morts qu'on veut envoyer dans les pays éloignez, Eo de les y faire arriver bien conditionnez (1747); Lewis Nicola, "An Easy Method of Preserving Subjects in Spirits," Transactions of the American Philosophical Society 1 (1769-71): 244-46. Ellis's Directions for transporting plants and seeds enjoyed a similarly international audience. Within a decade it was issued in five new editions, including translations into French and German. Ellis, Directions for Bringing Over Seeds and Plants . . . (London, 1771); John Ellis, Some Additional Observations on the Method of Preserving Seeds from Foreign Parts ... (London: W. Bowyer and J. Nichols, 1773); John Ellis, A Description of the Mangostan and the Bread-Fruit. . . to Which Are Added, Directions to Voyagers, for Bringing Over These and Other Vegetable Productions . . . (London: Edward and Charles Dilly, 1775); John Ellis, Anweisung wie man Saamen und Pflanzen aus Ostindien und andern entlegenen Lädern Frisch und grünend über See bringen kann ... (Leipzig, 1775); John Ellis, Description du mangostan et du fruit à pain . . a avec des instructions aux voyageurs pour le transport de ces deux fruits Ė autres substances végétales... (Rouen: P. Machuel, 1779).

37. Latour, Science in Action, 215-57. 
Their conclusions were based on the particular specimens they had received. Garden initially sent three specimens of the mud iguana-two small ones in spirits and the dried skin of a much larger specimen. Although Garden claimed that "the most essential characters of it" were visible in the dried specimen, the specimen's condition led Ellis to mistakenly identify the tail's outer membrane as a fin. Further, a dried skin of the animal could not be dissected, which severely limited anatomical investigations. Ellis initially concluded, on the basis of the specimen he received, that the mud iguana was "no more than a larva of a large kind of Lacerta," and that this fin would fall off when the hind legs developed. Yet when Linnaeus received one of the smaller specimens, he pointed to other anatomical features to raise doubts about Ellis's classification of the animal. By mid-1766, when Ellis presented the specimens to the Royal Society, the proper classification of the animal was still uncertain. The engraving of the mud iguana that accompanied Ellis's published description highlighted this uncertainty by including images of the English common newt alongside the Carolinian specimen (figure 4). ${ }^{38}$

A live specimen of the mud iguana would have definitively settled the dispute. The mud iguana, however, was a particularly difficult animal to transport. As the vernacular name suggests, it required a moist, muddy habitat and would quickly perish outside an aquatic environment. Further, Garden repeatedly stressed the fierce, predatory nature of the animal, which led South Carolinian blacks to be "much afraid" of it. It would be an unusual ship captain who would willingly take on such a difficult cargo. Although Garden promised to attempt the feat, in the interim he forwarded Ellis a large specimen in a pot of spirits. Garden defensively noted that Ellis "now [had] an opportunity of examining it carefully, both as to its external char-

38. Alexander Garden to Carl Linnaeus, May 18, 1765, John Ellis to Linnaeus, [August 1765], Ellis to Linnaeus, September 10, 1765 ("no more than a larva"), Linnaeus to Ellis, December 27, 1765, Ellis to Linnaeus, January 31, 1766, Ellis to Linnaeus, October 21, 1766, Garden to Linnaeus, August 4, 1766, Garden to Ellis, May 18, 1765 ("essential characters"), and Garden to Ellis, July 18, 1767, in Smith, Correspondence of Linnaeus, 1:320, 172, 174-75, 184, 185-87, 187-88, 321-23, 531, and 559-60, respectively; John Ellis, "An Account of an Amphibious Bipes," Philosophical Transactions 56 (1766): 189-92; John Ellis and John Hunter, "A Supplement to the Account of an Amphibious Bipes . . . Being the Anatomical Description of the Said Animal," Philosophical Transactions 56 (1766): 307-10. For the advantages of "wet specimens" (preserved in liquor) over their dried predecessors, see Harold J. Cook, "Time's Bodies: Crafting the Preparation and Preservation of Naturalia," in Smith and Findlen, Merchants and Marvels, 226-29, 240. 


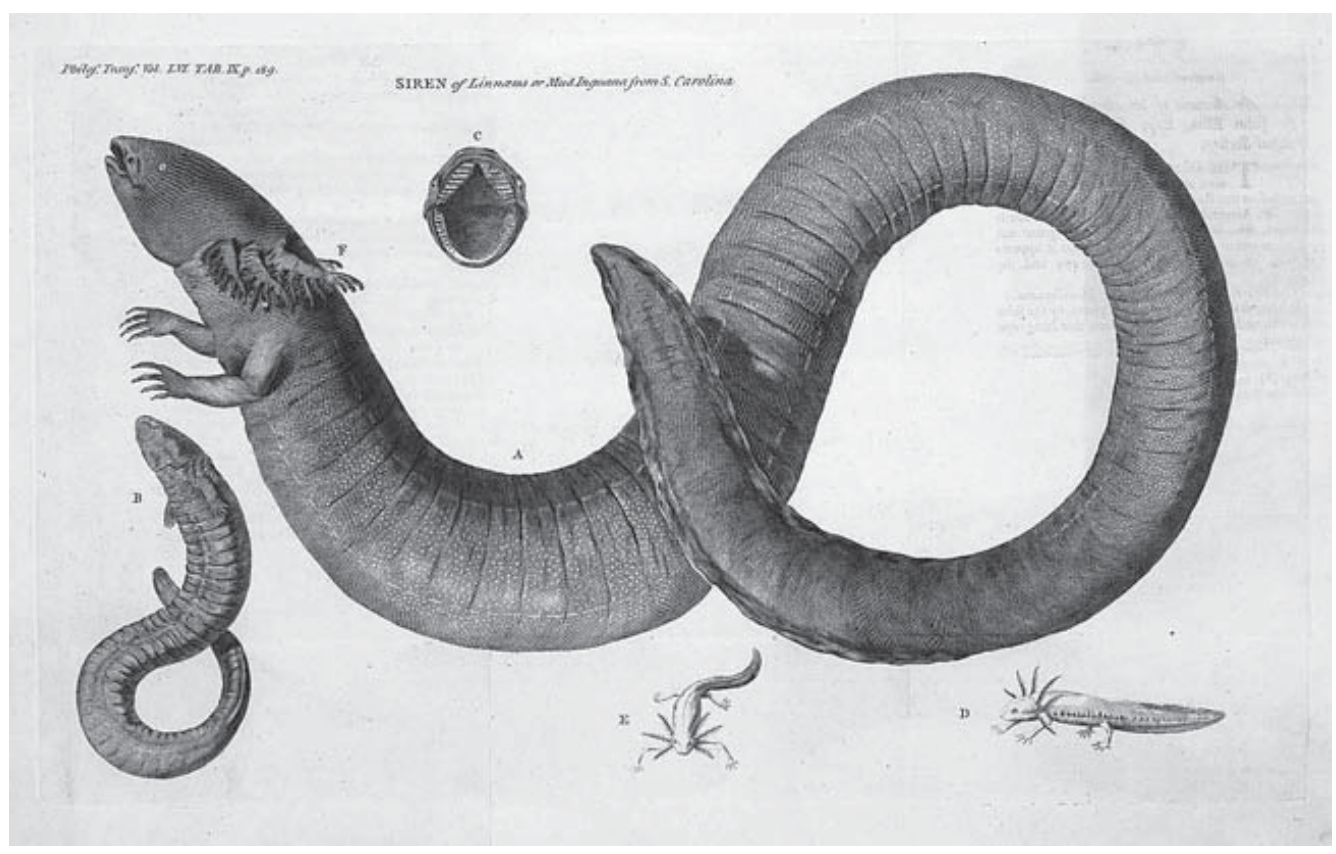

Figure 4. These two specimens of the mud iguana (figures A and B) were sent by Dr. Alexander Garden of South Carolina to support his claim that the animal represented an amphibian unlike any yet described. Misled by the condition of the specimens, Garden's correspondent, John Ellis, suggested instead that the specimens were merely larvae of more common four-legged lizards, such as the English common newt shown here (figures D and E). From John Ellis, "An Account of an Amphibious Bipes," Philosophical Transactions 56 (1766): 18992. Reproduced by permission of the Huntington Library, San Marino, Calif.

acters and the anatomy, in which I hope you will be accurate, as the specimen is large." 39

Once such a specimen was in front of him, Garden trusted that the only conclusion Ellis could draw was that the mud iguana represented a new

39. Alexander Garden to John Ellis, August 6, 1766, Garden to Ellis, June 2, 1767, Garden to Ellis, July 18, 1767 ("much afraid" and "specimen is large"), and Garden to Ellis, July 6, 1768, in Smith, Correspondence of Linnaeus, 1:550, 557, 560, and 565, respectively. Garden recommended that the engraving of the animal reflect its fierce nature: "Let me advise you to give it as lurid a look as possible, for it has one of the most lurid, torvous, threatening, surly, forbidding looks of any animal that ever I saw." Garden to Ellis, August 6, 1766, in Smith, Correspondence of Linnaeus, 1:550. Ultimately, Linnaeus sided with Garden, naming the Carolinian animal Siren lacertian and placing it in a new class of Amphibia (Sirenidae). Edmund Berkeley and Dorothy Smith Berkeley, Dr. Alexander Garden of Charles Town (Chapel Hill: University of North Carolina Press, 1969), 189-97. 
species. Knowledge production, the South Carolinian suggested, depended on specimen preservation and trans-Atlantic transportation. Yet preservation and transportation represented two of the most challenging technical problems confronting eighteenth-century naturalists. With time and patience, naturalists refined the material practices of preservation and trans-Atlantic transport. They learned to identify the key dangers of the ship's environment and how to limit the effect of these dangers through the manner in which specimens were preserved, packed, and placed on board a vessel. Simply transporting a specimen intact across the Atlantic was not always sufficient; some studies required that a plant or animal be in a particular stage of development or be preserved in a particular manner. Although seeds were much easier to transport than living trees, a naturalist might have to wait a lifetime for seeds to mature. Duhamel du Monceau's study of North American trees was advanced considerably by his ability to work with transplanted specimens, rather than trees grown from seed. In a literal way, the objects pulled out of ships' holds shaped the natural knowledge subsequently produced. Material practices had epistemological consequences. ${ }^{40}$

\section{CONCLUSION}

The birds, butterflies, and plants retrieved from the holds of eighteenthcentury vessels were the stuff of natural history, essential to the work of naturalists. Such material objects, and the social and material technologies that facilitated their circulation, made possible the intellectual advances credited to metropolitan naturalists such as Duhamel du Monceau, Réaumur, and Ellis. Through trial, error, and bitter experience, French and British naturalists on both sides of the Atlantic moved toward the development of an environmental science of ships. This cluster of practices developed in response to the particular dangers of the shipboard space and consequently shaped the knowledge produced from within it. Therefore ships, as much as gardens, museums, and cabinets of curiosity, constituted a space of natural history.

The various refinements made to the social and material practices of transport need not distract us from the inherent difficulties of transporting delicate seeds, plants, and animals across an ocean. Ultimately, the natural

40. Henri-Louis Duhamel du Monceau, Traité des arbres et arbustes qui se cultivent en France en pleine terre (Paris: H. L. Guerin \& L. F. Delatour, 1755). For specimen preservation as a major technical challenge confronting eighteenthcentury naturalists, see Farber, "The Development of Taxidermy," 550. 
and social spaces of eighteenth-century vessels were defined by their uncertainty. Such uncertainty might take the form of extraordinary events such as severe storms or capture by foreign navies, or the less visible but often more threatening presence of rats, excessive moisture, and inattentive crews. Regardless of the particular dangers, once they were out to sea, the safety of natural history objects was largely beyond the naturalist's control. Redundancy was the only sure solution when years' or even lifetimes' worth of work collecting and preparing specimens could be lost in an instant.

Such dangers of loss haunted naturalists regardless of nationality. Employing a comparative lens to examine the material and social practices of maritime transport brings into view the consequences of imperial differences for scientific practices. In the case of material practices of transport, a comparative approach reveals continuities for the most part. The physical dangers of the shipboard environment transcended imperial boundaries; consequently, the material practices of French and British naturalists developed along parallel lines. Further encouraging such similarity was the transnational circulation of printed scientific works, including those like Réaumur's that highlighted preservation techniques. Structural differences between science in the two empires were most apparent in the social practices naturalists employed to secure berths for their specimens and to find individuals to superintend their care while at sea. These differences in social practices demonstrate that the consequences of the state's involvement in science went beyond the question of who was footing the bills. The institutional support afforded to French naturalists allowed them to draw on the extensive networks of the Académie and the French Crown, rather than rely exclusively on the routes and rhythms of trans-Atlantic commerce. The particular contexts within which naturalists in the eighteenth-century Atlantic worked shaped the knowledge they produced. Theirs was a knowledge grounded in a particular time and place, regardless of universalizing Enlightenment claims to the contrary.

The differences between the two scientific networks partially diminished in the last years of the eighteenth century. During this period the British began to move toward the French model of state-sponsored science. The voyages of Cook and the infamous attempt to introduce breadfruit into the Caribbean are only the most familiar consequences of this new state support for science in the British Empire. For those like Joseph Banks, at the forefront of such efforts, the French model loomed large as they promoted such changes. State support for science in France only increased in the wake of the Seven Years' War and subsequent efforts to reform colonial and naval administration. Irrespective of nationality, naturalists and gardeners in the 
late eighteenth and early nineteenth centuries drew on the knowledge and techniques of transport and preservation developed in the Atlantic world during the first half of the eighteenth century. Many of these practices were also employed to transport plants, seeds, and animal specimens on longer voyages to the Pacific and Indian Oceans. Improvements in plant transportation were generally incremental until the invention of Wardian cases in 1820. These sealed glass cases provided a stable and isolated environment for plants at sea and thereby dramatically increased the success rate of transplantations. ${ }^{41}$

Eighteenth-century natural history depended on the observations and collections gathered by individuals throughout the Atlantic world and beyond. New natural knowledge emerged from the circulation of specimens, instruments, and narrative descriptions; natural history was, in essence, a science of objects in motion. If movement was a mode of knowledge production, we must also attend to the social and material practices that made objects mobile. The examples of Duhamel du Monceau's American trees and Garden's mud iguana demonstrate the importance of considering material objects and the logistical problems they created for travelers and naturalists. Highlighting the objects of natural history and their trans-Atlantic passage also returns the Atlantic Ocean to its rightful place at the center of this Atlantic history.

41. Drayton, "A l'école des Français"; John Gascoigne, Science in the Service of Empire: Joseph Banks, the British State and the Uses of Science in the Age of Revolution (Cambridge, Cambridge University Press, 1998); Tim Fulford, Debbie Lee, and Peter J. Kitson, Literature, Science and Exploration in the Romantic Era: Bodies of Knowledge (Cambridge: Cambridge University Press, 2004); David Mackay, In the Wake of Cook: Exploration, Science, E̋ Empire, 1780-1801 (New York: St. Martin's Press, 1985); Allain, Voyages et Survie; McClellan, Colonialism and Science; Roger L. Williams, French Botany in the Enlightenment: The Ill-Fated Voyages of La Pérouse and His Rescuers (Dordrecht, The Netherlands: Kluwer Academic Publishers, 2003); Rigby, "Politics and Pragmatics," 97. 